\title{
Implication of the CSR and cultural model features in Romanian energy sector ${ }^{4}$
}

\author{
Article history: \\ Received: 1 August 2014 \\ Sent for revision: 10 September 2014 \\ Received in revised form:22 October 2014 \\ Accepted: 3 November 2014 \\ Available online: 23 December 2014
}

\begin{abstract}
Energy has become a major factor in promoting and achieving a highly competitive economy during last couple of decades. The Romanian energy sector has passed through a massive reform process with divergent effects and restrictive implication both for industry and population. In this context it is very important that the major energy business players respect and follow the cultural model framework and their own CSR policies. The main aim of the paper is to analyze the implication of the CSR and cultural model features in Romanian energy sector.
\end{abstract}

Keywords: business model, CSR, cultural model, economic structures, energy

\section{Uticaj DKO i elemenata modela kulture u energetskom sektoru Rumunije}

Apstrakt: Energija je postala ključni faktor u unapređenju i uspostavljanju konkurentne pozicije nacionalnih privreda u prethodnim decenijama. Energetski sektor u Rumuniji je prošao kroz proces obimnih reformi sa divergentnim efektima i restriktivnim posledicama kako na industriju tako i na stanovništvo. U tom kontekstu veoma je značajno da su glavni učesnici u energetskom sektoru uključeni i primenjuju model kulture i sopstvene politike društvene korporativne odgovornosti (DKO). Cilj ovog rada je da se analizira uticaj DKO i modela kulture u energetskom sektoru Rumunije.

\footnotetext{
${ }^{1}$ Petroleum-Gas University of Ploiesti, ajvasile@upg-ploiesti.ro

2 Petroleum-Gas University of Ploiesti, Prahova, Romania

${ }^{3}$ The Bucharest University of Economic Studies, Bucharest, Romania

${ }^{4}$ This paper is supported by the Sectoral Operational Programme Human Resources Development (SOP HRD), financed from the European Social Fund and by the Romanian Government under the contract number SOP HRD/159/1.5/S/136077.
} 
Vasile J.A. et al.: Implication of the CSR and cultural model features in Romanian...

Ključne reči:poslovni model, DKO, kulturni model, struktura privrede, energija

\section{Introduction}

In a context of the actual and consecutive inland economic transformations, both structural and functional, the importance of the energy resources has occurred as a highly important analysis subject not only for the business environment but also for the economic system development. The energy sector evolution has become actual and very stringent for a transitional economy, such as Romania, which is looking for sustainable development and achievement of more effective energy independence from imports. The intensive economic reform of the inland economy reflects mainly the actual structure of the economic sectors, with influences from the cultural model with the new form of the development. Despite the previous model of the economic structures, the new economic structure is less developed than the one before 1989 , with a high dependence on investments in order to become competitive.

The evolution of the Romanian economy, at least in the period of last twentyfour years of transition is marked by an emphasized deindustrialization which developed inconsistencies between national model of development and the convergence imposed by European economic and cultural model governed by the free market economy criteria. Achieving the best convergence with the European development model requires both the understanding of the national development models adapted to the internal structures of society and also importing the transformations which favor reducing the disparities in sustainable development and a functional economy.

Romania's integration with the European economic area has required major steps in achieving all the criteria imposed by the EU-28 energy policy in order to become a functional part of the energy network, with competitive standards needed to be implemented. Adapting to these economic and cultural requirements and the specific European consumer model imposed a need for massive restructuring of the inland energy sector for becoming more competitive. Despite the reforms' measures, the sector competitiveness has not been improved and the convergence with specific policies in the field has indicated significant discrepancies. Energy is a field of utmost importance to be harmonized with common European policies taking into account the inland economic specificity.

Assuming that a functional and highly competitive economy cannot be achieved without the existence of a sustainable energy sector, it is necessary to adapt all the policy and economic instruments for formation of competitiveness requirements, taking into account that energy is a mandatory component in every economic activity. In this case the energy sector must 
Vasile J.A. et al.: Implication of the CSR and cultural model features in Romanian...

ensure a continuous and high-quality supply of energy resources to entire national economic system.

In this paper we analyze main transformations that marked this sector from the multiple perspectives, given a strong component of social responsibility that modern enterprises have to consider. As stated in EU-28 policy documents (European Commission, 2011), the EU energy policy is based on achieving the objectives of supply security, competitiveness and sustainability, while its external dimension plays a crucial role for all of them. (European Commission, 2011).

Developing and implementing the common energy policy requires development of energy infrastructure in every member state and increasing compatibility in order to build interconnection between them. In the EU Strategy for security of energy supply and international cooperation there are stated four main objectives for increasing the energy independence degree at EU-28 level. According to the European Commission (2010) they are:

- Developing the external dimension of the EU internal energy market;

- Strengthening partnerships for a guaranteed, sustainable and competitive energy;

- Facilitating access to sustainable energy in developing countries;

- Better promotion of EU policies beyond its borders. (European Commission, 2010).

Designing and building strategic energy partnership is one of the most essential elements to be promoted more actively, and beyond the limitations imposed by the cultural and political or geographical models restrictions. In this context, both existing relations between Member States and national energy policies must be taken into consideration as well as legal and economic instruments used in the field. They also should be used to increase the energy policy convergence, including promotion of the renewable energy as part of developing scenarios as remarked in some studies, such as Dusmanescu et al. (2014)

Table 1 synoptically presented requirements for the implementation of the strategic energy partnerships, depending on goals and instruments used in achieving objectives as it is stated in European Commission, 2011.

Corporate social responsibility (CSR) is one of the most important topics of contemporary research due to its implications on changing the way corporation do the business. Over time corporations have started with little reflection on environment and society issues, until public reaction has made them reconsider those aspects and take into account their influence and diminish the negative aspects of their activity. (Tănăsescu et al., 2008) 
Vasile J.A. et al.: Implication of the CSR and cultural model features in Romanian...

Table 1. The EU energy partnerships requirements based on scopes and instruments

\begin{tabular}{|c|c|c|c|c|}
\hline & $\begin{array}{l}\text { With our } \\
\text { neighbors I } \\
\text { market } \\
\text { integration } \\
\text { partners }\end{array}$ & $\begin{array}{lrr}\text { With } & \text { our } & \text { key } \\
\text { energy } & \text { suppliers } \\
\text { and } & \text { transit } \\
\text { countries } & \end{array}$ & $\begin{array}{l}\text { With key energy } \\
\text { players } \\
\text { worldwide }\end{array}$ & $\begin{array}{l}\text { With developing } \\
\text { countries }\end{array}$ \\
\hline Scope & $\begin{array}{l}\text { All issues } \\
\text { covered by } \\
\text { the EU } \\
\text { energy policy }\end{array}$ & $\begin{array}{l}\text { Wide range of issues } \\
\text { of common interest } \\
\text { such as security of } \\
\text { supply/demand, } \\
\text { industrial } \\
\text { cooperation, trade } \\
\text { and investment } \\
\text { issues }\end{array}$ & $\begin{array}{l}\text { Focus on priority } \\
\text { issues like } \\
\text { research and } \\
\text { innovation, low } \\
\text { carbon } \\
\text { technologies, } \\
\text { energy efficiency, } \\
\text { standards }\end{array}$ & $\begin{array}{l}\text { Low emission } \\
\text { development } \\
\text { strategies, energy } \\
\text { access, policy and } \\
\text { regulatory } \\
\text { frameworks, } \\
\text { promotion of } \\
\text { energy generation } \\
\text { and transmission, } \\
\text { renewable energy }\end{array}$ \\
\hline \multirow[t]{3}{*}{ Instruments } & $\begin{array}{l}\text { Energy } \\
\text { Community } \\
\text { Treaty }\end{array}$ & $\begin{array}{ll}\begin{array}{l}\text { Strategic } \\
\text { dialogues }\end{array} & \text { energy } \\
\end{array}$ & $\begin{array}{l}\text { Ad hoc energy } \\
\text { cooperation }\end{array}$ & $\begin{array}{l}\text { Ad hoc energy } \\
\text { cooperation }\end{array}$ \\
\hline & $\begin{array}{l}\text { Instruments } \\
\text { Neighborhood } \\
\text { instruments, } \\
\text { partnership } \\
\text { agreements, } \\
\text { energy } \\
\text { Energy Charte }\end{array}$ & $\begin{array}{l}\text { Inder the European } \\
\text { Policy, crisis response } \\
\text { and/or specific } \\
\text { and cooperation } \\
\text { covering inter alia } \\
\text { Treaty }\end{array}$ & $\begin{array}{l}\text { Other applicable } \\
\text { instruments }\end{array}$ & $\begin{array}{l}\text { Instruments under } \\
\text { the EU } \\
\text { development policy } \\
\text { crisis response } \\
\text { instruments }\end{array}$ \\
\hline & \multicolumn{4}{|c|}{ Trade Agreements } \\
\hline
\end{tabular}

Source: authors` based on (European Commission, 2011, COM/2011/0539 final)

The roots of CSR existed for centuries in different forms, where the best known, before the $20^{\text {th }}$ century, were philanthropic activities as a way to return some of the accumulated wealth to community. The modern CSR concept and all its components have developed in the last 60 years, starting with the movements in the 1960s from the USA that requested an increase of social responsibility from companies. This request got its answer in the early 1970s when new regulation strengthened the legal frame regarding environment, social protection, and health and consumer safety.

The concept of CSR spawns important debates among researchers from different fields like economics, sociology and political science. Many definitions have been provided due to CSR complexity, but we consider Corporate Social Responsibility as appropriate, being "the continuing commitment of business to behave ethically and contribute to economic development while improving the quality of life of the workforce and their families as well as of the local community and society at large". (Holme and Watts, 2000). 
Vasile J.A. et al.: Implication of the CSR and cultural model features in Romanian...

Among the supporters of CSR, Carroll has some of the most important additions with the pyramid of CSR from Fig.1 stating that CSR has four components: economic components (maximize earnings, be profitable, be competitive, be efficient), legal components (obey the law, comply with regulations, fulfill your legal obligations), ethical components (do what is expected morally and ethically), and philanthropic components (promote and finance projects that improve life quality, assist educational institutions).

An important opponent of CSR was Friedman who stated that the role of a company is to engage in businesses that allow it to get as much profit as it can, without breaking any rule of the society. He also argued that a company is not a person and therefore it has no social responsibility to society, unlike the owners of the company who should be socially responsible (Friedman, 1970).

Another important debate was generated by the influence of CSR on company profitability and many studies were made to show if there is a correlation between them. There have been several attempts to quantify the influence of CSR on business profitability, where some used the event study methodology to see if there is a short-term influence of CSR over business finances (Posnikoff, 1997; Teoh, Welch and Wazzan, 1999; Wright and Ferris, 1997, Chivu et al., 2007), providing different results, while others used corporate social performance as a measure of CSR and compared it with accounting data to show a connection with a company's profitability (Ciutacu et al.,2005, Aupperle, Carroll, and Hatfield, 1985; McGuire, Sundgren and Schneeweis, 1988; Waddock and Graves, 1997) also with no consistent, or divergent results.

\section{Figure1. Corporate Social Responsibility pyramid}

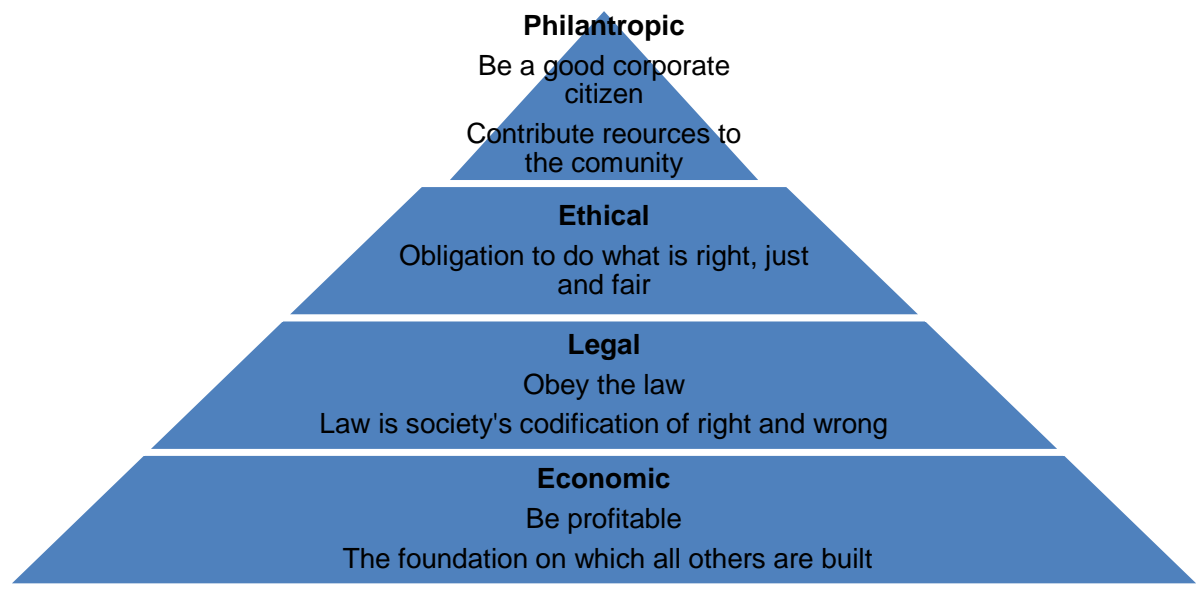

Source: authors` based on (Carroll 1991) 
Vasile J.A. et al.: Implication of the CSR and cultural model features in Romanian...

Although the results of these studies have been mixed, some studies have showed that "a firm's level of CSR will depend on its size, level of diversification, research and development, advertising, government sales, consumer income, labor market conditions, and stage in the industry life cycle" (McWilliams and Siegel, 2001). Furthermore, a positive correlation has been observed between CSR and expenses in R\&D and advertising.

More debates have been reviewed on the topic of who should initiate CSR actions. According to the literature there are three possibilities. First one is CSR as a duty imposed by government regulation, with the result of similar CSR programs because of the obligation to comply with regulation. The second form of CRS is not led by government, but by associations of companies, activist and responsible managers that initiate CSR framework and disseminate the benefits of CSR, promoting its use in their industry. In the case of developing countries CSR has been promoted by international financial institutions like the World Bank. The third form is based on the launch of CSR at company level in the search for strategic advantage and the transformation of different social and environmental threats in opportunities as a competitive advantage. In the last years we can observe an interconnection between the three forms, as the separate forms proved to be inadequate for the global aspect, while not all states could act to promote CSR practices in their national companies. This form of hybrid regulations brings at the same table political actors, social actors and economic actors and resulted in the creation of international standards (Waddock, 2008).

The most important international frameworks used for CSR reporting are: The United Nations Global Compact jointly used with OECD Principles for Corporate Governance, mentioning the Global Reporting Initiative and also the ISO 26000.

OECD principles for corporate governance have the role to guide the OECD or non-OECD countries, in their quest for a better evaluation of CSR framework. The principles are aimed at publicly traded companies, but they can be used for other types of companies too, like state owned or privately held companies. OECD principles for corporate governance cover the next areas: ensuring the basis for an effective governance framework, the rights of shareholders and key ownership functions, the equitable treatment of shareholders, the role of stakeholders in corporate governance, disclosures and transparency, the responsibilities of the board (OECD 2004).

The United Nations Global Compact has the role to help businesses in their commitment to harmonize their actions and operate with ten universally accepted principles. The main areas covered by these principles are: general human rights, labor and quality of labor and living condition, environment and anti-corruption prevention. The principles are a result of four other acts (The Universal Declaration of Human Rights, The International Labor 
Vasile J.A. et al.: Implication of the CSR and cultural model features in Romanian...

Organization's Declaration on Fundamental Principles and Rights at Work, The Rio Declaration on Environment and Development and The United Nations Convention against Corruption). The Global Compact aims to be one of the leading voluntary initiatives to promote CSR ensuring that social actors and businesses meet and generate a sustainable and equitable economy.

The Global Reporting Initiative is one of the most important institution that help organizations to become more sustainable by the use of sustainability reporting. GRI made the Sustainability Reporting Framework that is used by companies to report their achievements in CSR. The Framework includes reporting guidelines, sector guidance and other resources and has become one of the most used tools by organizations of all sizes and sectors to communicate their sustainability performance.

ISO 26000 - Social Responsibility provides guidance for a socially responsible way of doing businesses. ISO 26000 contains seven core subjects: organizational governance, community involvement and development, human rights, consumer issues, labor practices, the environment and fair operating practice. This standard is not used for certification but has as main objective a common understanding of CSR.

Regarding the position of companies towards CSR, Gray, Own and Adams outline seven possible positions as presented in Fig. 2. Pristine capitalists consider the CSR as an impediment to businesses even though they acknowledge that there are environmental and social costs in the way they conduct businesses. Expedients take into account CSR objectives only if they have a positive contribution to their economic interest. Supporters of social contracts are represented by companies that are concerned about everything affected by their decisions and they agree on contracts with all affected parties.

Social ecologists are the ones that embrace CSR as a way to offset their negative influence on environment and society, marking a turning point in CSR promotion. Socialists seek equilibrium between organizations and theirs economic and social interests. Radical feminists seek the implementation of feminine values like cooperation, being known that business is usually of masculine nature, and therefore the source of many social problems. Deep ecologists postulate that humans have no rights to resources over other beings and they promote sustainability and self-sufficiency. 
Vasile J.A. et al.: Implication of the CSR and cultural model features in Romanian...

Figure 1. Corporate social responsibility positions

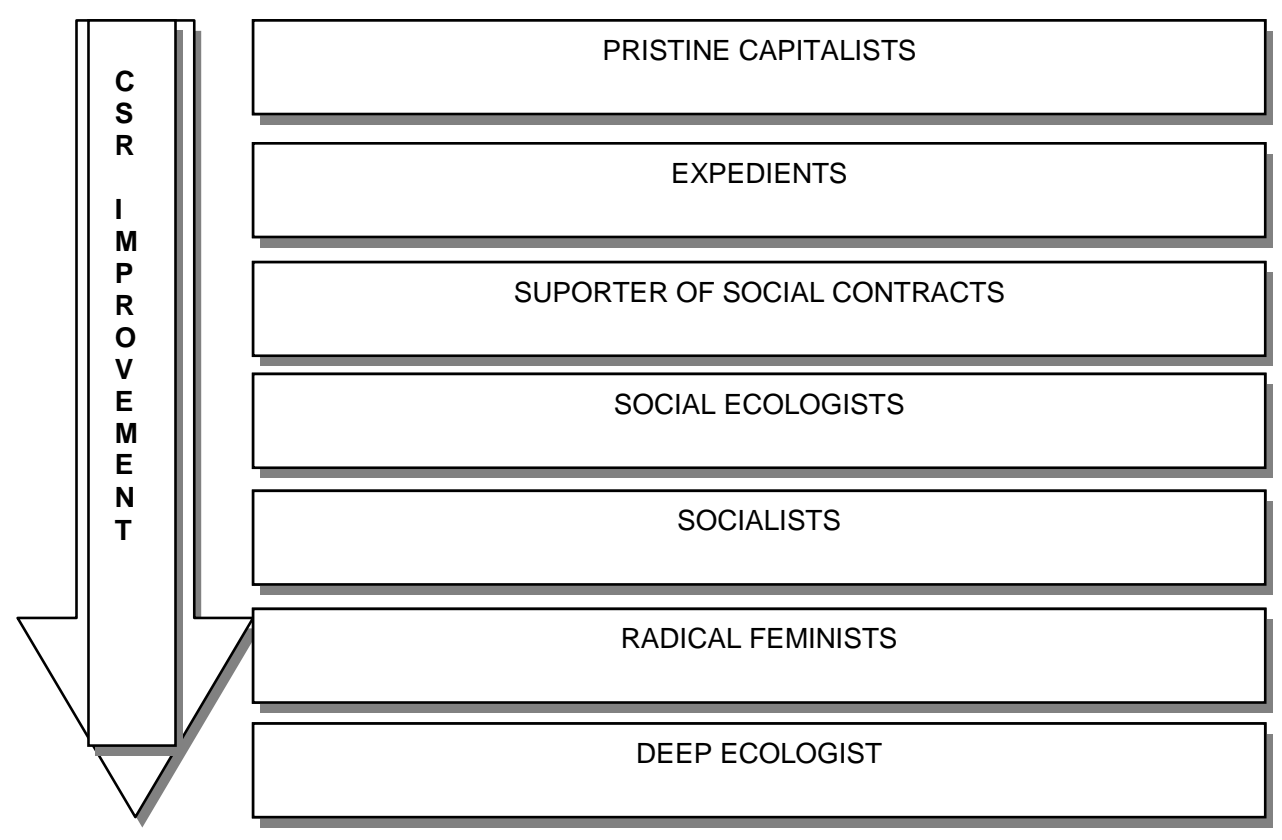

Source: adapted from (Gray et al.,1996)

\section{Social responsibility in the energy sector - international concern}

Internationally, social responsibility concerns have intensified after 2000. In addition to initiatives with general character; there are also initiatives of the energy sector. The social partners in energy EPSU (European Public Service Unions), EMCEF (European Mine, Chemical and Energy Workers Federation) and Eurelectric (Union of the Electricity Industry) adopted after a series of discussions, a joint declaration on CSR in 2004.

The Global Reporting created a supplement specifically for the energy sector intended for entities involved in the energy production, transmission, grid distribution or retail sale of electricity. This supplement has the advantage of being used by any organization, regardless of its size, type of property or the activities carried out. In addition, this supplement is based on specific sectoral G3 guide and includes guidelines for reporting and performance indicators, 
Vasile J.A. et al.: Implication of the CSR and cultural model features in Romanian...

specific for electricity sector. Due to the flexibility of the established principles and indicators, and the existence of specific indicators for the energy sector, the Global Reporting Initiative is a tool often used by companies in the sector.

\section{Romanian energy sector in context of cultural model future evolution and corporate social responsibility}

Given the role of energy in the economy and society, the sector's operation is supervised by the public authorities who develop different strategies and action plans in the medium and long term. In Romania, the overall objective of the energy sector strategy is (Ministerul Economiei si Industriei, 2011) "to meet the energy needs both now and in the medium and long term, at a price as low as possible, suitable for a modern market economy and for a decent standard of living in conditions of quality, supply safety in accordance with the principles of sustainable development".(Ministerul Economiei si Industriei, 2011).

Table 2. Evolution of active enterprises by number and activity of national economy, in Romania, 1992-2012

\begin{tabular}{|c|c|c|c|c|}
\hline Year & Total & Mining and quarrying & Manufacturing & $\begin{array}{c}\text { Electric and thermal energy, } \\
\text { gas and water }\end{array}$ \\
\hline 1992 & 130076 & 89 & 20678 & 209 \\
\hline 1995 & 304359 & 170 & 34404 & 276 \\
\hline 2000 & 308064 & 276 & 41547 & 334 \\
\hline 2005 & 433030 & 676 & 57900 & 584 \\
\hline 2006 & 461812 & 734 & 58878 & 615 \\
\hline 2007 & 499857 & 903 & 59945 & 506 \\
\hline 2008 & 534525 & 1083 & 57305 & 609 \\
\hline 2009 & 519441 & 1234 & 54652 & 885 \\
\hline 2010 & 470080 & 1166 & 48933 & 924 \\
\hline 2011 & 430608 & 1108 & 45052 & 1050 \\
\hline 2012 & 449482 & 1098 & 46004 & \\
\hline
\end{tabular}

Source: authors based NIS (2014)

As it can be remarked from table 2, the evolution of active enterprises national in Romanian economy during 1992-2012 has experienced the transitional periods to the market economy. The total number of enterprises has increased from 130076 units in 1992 to 430608 units in 2011. Despite the massive increases of the total number of enterprises, the industrial structure has continued to experience an important destructuration. This evolution is the result of the downward process of the industrial structure and the reform process effects that managed just to disintegrate and shrink the structures. The figure 3 presented the evolution of the enterprises ` number during 1992- 
Vasile J.A. et al.: Implication of the CSR and cultural model features in Romanian...

2012, with regard to the activities covered by this paper (energy related sectors).

Figure 3. Evolution of the enterprises related to energy sector, 1992-2012

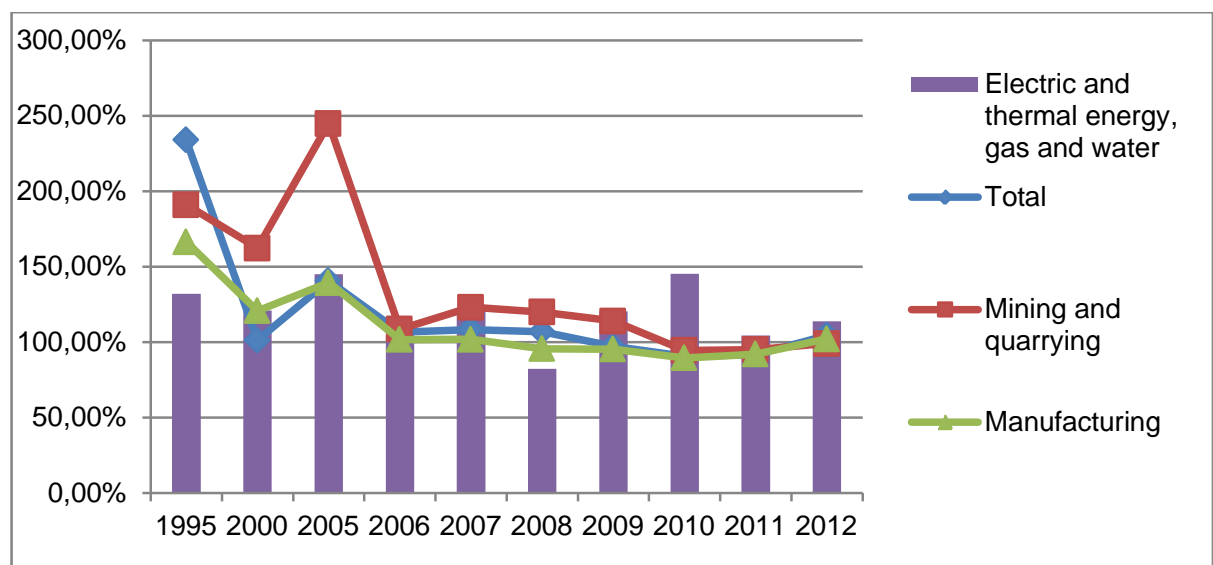

Source: authors based on NIS (2014)

Romania, as an EU member has assumed energy and environmental policy of the EU and thus strategic objectives, namely: energy security, sustainable development and competitiveness. European energy policy was built starting from sustainable development's principles to be applied in the context of climate change, increasing energy consumption and increasing prices of oil and natural gas. The economic and political context led reconfiguration of global energy policy which pays special attention to renewable energy and improving energy efficiency.

Therefore, European energy policy has the following objectives: "consumer access to affordable and stable energy sources, sustainable development of generation, transmission and energy consumption, security of energy supply and reducing emissions of greenhouse gases." The UE package regulations on energy policy and climate change was adopted in 2008 and set "20-20-20 targets" aimed at reducing emissions of greenhouse gases (at least 20\%), increased (by 20\%) share of renewable in total energy consumption and $20 \%$ reduction in primary energy consumption.

The energy market in Romania is decentralized; the activities regarding production, transport, distribution and supply are distinct, being run by various local or foreign owned companies.

Romania's energy sector is dominated by state-owned companies, but they are in the process of technical and institutional modernization. Besides the major investments mainly carried out on financing from large private banks 
Vasile J.A. et al.: Implication of the CSR and cultural model features in Romanian...

and international financial institutions such as International Bank of Reconstruction and Development, European Bank of Reconstruction and Development and European Investment Bank, these companies have become major operators and the capital market by launching initial public offers (IPOs) to quotation on local stock exchange or public offerings of bonds to attract additional funds. Although, at this stage, social involvement of these companies is not at the level of achievement of foreign companies, the pressure from shareholders and investors will lead to an improvement in their social responsibility behavior, considering both listing and bonds issue actions.

The main players in the energy market in Romania are state owned companies - Transelectrica, Nuclearelectrica, Electrica, Hidroelectrica and Termoelectrica - set up from divided former National Electricity Company Electrical Company.

Company Translectrica, although being listed on the Bucharest Stock Exchange since 2006, has a low social involvement. The social responsibility policy has as its main focus areas of art and culture, education, humanitarianism, environment, community development, promotion of responsibility towards employees and business partners, and corporate volunteering. Besides CSR policy, the company has a Code of Ethics and quality management policy; environment, occupational health and safety are available on the company website. Furthermore, according to the current regulations (Government Decision no. 878/2005 on public access to environmental information) the company publishes information on the impact of public company operations on the environment. In annual reports, the company has separate sections where it presents issues like environmental implications, governance and social responsibility.

As a proof of performance the company's shares are included in the reference basket for local stock indices (BET, BET-XT, BET-NG, BET-C, BVB) and international indexes like: DowJones Wilshire Global Indexes (Dow Jones Wilshire Global Total Market Index SM, Dow Jones Wilshire Index Romania SM; Dow Jones Wilshire Index Electricity SM).

The company Hidroelectrica is the largest electricity producer in Romania, with the lowest cost. However, the correlation between certain internal and external factors such as weather, damaging commercial contracts and bad management led to opening insolvency procedure in June 2012. Although the company is in the process of reorganization, it has developed a Code of Ethics in 2014 and a corporate governance code. Although IPO was announced for 2014, re-initiation of insolvency procedure resulting from the court appeals by some lenders, this event cannot take place until fulfillment of all legal conditions for end of insolvency procedure. 
Vasile J.A. et al.: Implication of the CSR and cultural model features in Romanian...

Electrica is the largest distributor and supplier of electricity in Romania, and is currently listed on the Bucharest Stock Exchange by launching an initial public offering. The recent listing on the local stock exchange has not led to an intense social involvement of the company, the only publicly available documents being ethical code for employees. Through the Integrated Quality Management System and Environment, Occupational Health and Safety, the company achieves a balance between the economic, social and environmental characteristics of the energy sector.

Nunclearelectrica is the only company in Romania that produces nuclear power. Since 2013, the company is listed on the Bucharest Stock Exchange, following an initial public offering. The social involvement is low and it is not influenced by the public nature of the company. The only major project involving the company's "Emergency Social Program to improve living conditions for Cernavoda and staff of the plant construction and operation" was started with a decision by the government in 1991. The targets of the program involve building of utilities, social and cultural constructions for Cernavoda city and housing assembly for operating personnel of the company.

Enel Group is the largest Italian electricity company, active in Romania since 2005, when it bought from the Romanian Government the majority package of shares of Dobrogea Electrica and Banat Electrica. Currently, its operations in Romania are complex, and the company is involved in the production, supply and distribution of electricity through various specialized companies. Enel Group is now the leading private investor in the Romanian energy sector.

Enel's social involvement is particularly intense at international level considering the large number of companies of the group present in 40 countries. Field of activity, of both the parent company and group of 14 companies operating in countries like Italy, Spain, Russia, Argentina, Brazil, Chile and Peru, has made the management group to design a social responsibility strategy aimed at combating corruption, protecting the environment and improving relations with communities and working people. In this regard, Enel joined the Global Compact in 2004 and the "Partnering against Corruption Initiative" launched by the World Economic Forum at Davos in January 2005.

Furthermore, Enel promotes its own environmental policy that is based on three fundamental principles: safeguarding the environment, improving the environment and promoting features of products and services, creating corporate value. Concern for the environment is real and the measures taken by the company are described, and the results are quantified and published on the annual environmental report, available on the company's website.

Enel uses many tools of social responsibility (Enel, 2013) : 
Vasile J.A. et al.: Implication of the CSR and cultural model features in Romanian...

- Code of Ethics, developed since 2002, which sets the rules of conduct of employees, shareholders, suppliers, competitors, society and environment;

- Zero Tolerance of Corruption Plan, adopted in 2006, which is based on the transparent and internationally promoted principles by Transparency International;

- Human Rights Policy adopted in 2013 and through Enel aligns with the United Nations guidelines on Business and Human Rights;

- Integrating environmental, social and governance aspects into the Procedures of risk management;

- Developing and publishing since 2006 the Sustainability report and application of the reporting guidelines issued by the GRI Global Reporting Initiative;

- Involvement in numerous social causes such as education, culture, and sports. (Enel, 2013)

Given the particular domains group, special attention is given to responsibility for the environment, acting for the development of renewable energy, energy efficiency and development of clean equipment (such as project development of alternative technologies for coal burning). Moreover, several programs of social responsibility were implemented such as "Zero Emissions" (partnerships signed with universities and research institutions in order to find methods of limiting the achievable emission of greenhouse gases)

At the global level, the Enel's activities regarding social responsibility are recognized by selecting its shares in famous international indices, including sustainability indices. Thus, the Enel's shares are part of indices like CDP Italy Climate Disclosure Leadership Index 2014, STOXX Global ESG Leaders Index, FTSE4Good index, Euronext-Vigeo World 120, Euronext-Vigeo Europe 120, Euronext-Vigeo Eurozone 120 and Newsweek Green Ranking.

French group - GDF SUEZ is present in Romania since 2005 when it bought a majority stake in Distrigaz Sud, a state-owned enterprise. In time, the activity of the group has expanded to the production of electricity from renewable resources. In this sense, two wind farms were created in the south of the country.

The main stakeholders namely employees, suppliers and customers are treated appropriately by the company by promoting four principles: to act in accordance with laws and regulations, to instill a culture of integrity, loyalty and honesty, and to prove respect to others. These principles are implemented through guide of ethical practices, guide of the relationships with suppliers, and trade relations guide.

Given the nature of activities, the concern for the environment is more intense in the case of GDF Suez, and thus environmental and social responsibility policy was developed in the early 2014 . The Group attempts to meet the 
Vasile J.A. et al.: Implication of the CSR and cultural model features in Romanian...

challenges arising from the growing demand of energy (assumption for the year of 2050 is double consumption per capita) and the need to reduce GHG Emissions.

The will for corporate social responsibility is very intense, and thus stakeholders ' consultation was held in 2012 to determine the directions of action in this area. The CSR activity focuses on health, education, social and environmental. Moreover, a social responsibility platform ("Energy for good works") it was created.

The presence in 70 countries, being listed on three exchanges (stock exchanges from Brussels, Luxembourg and Paris), the inclusion of shares in the major international indexes (CAC 40, BEL 20, DJ Stoxx 50, DJ Euro Stoxx 50, Euronext 100, FTSE Eurotop 100, MSCI Europe and ASPI Eurozone and ECPI ethical Index EMU), including ethical indexes demonstrating the promotion of the social responsibility, at international level, is not simply a marketing strategy.

German company E.on is a leading provider of electricity, which runs business in Europe, Russia, Asia, North America and South America. Its social involvement is particularly intense and tools used are multiple. In 2005, the company joined the Global Compact principles, and in 2007 it joined the World Business Council for Sustainable Development. Other issues affecting CSR tools are Human Rights Policy, Responsible Procurement Policy Global Climate Change and Environment or Policy.

E.on's social involvement is a process that was initiated at the beginning of the 2000s, and the first CSR report was published in 2004. The policy of social responsibility was updated periodically, the last time in 2011 , and it was adapted to the new specific requirements of energy market and the new target set by the company management, namely providing cleaner \& better energy. The main areas of interest are: environmental management, human rights, Responsible biomass procurement and purchasing, community, Health and Safety.

The company bases the CSR reporting on the guidelines of the Global Reporting Initiative (GRI). In addition, taking into account the field of activity, the final version of the Electric Utility Sector Supplement (EUSS) dated April 2009 is used. The recognition of the company's social involvement is demonstrated by the selection of shares issued in some of the sustainability indexes among as: Dow Jones Sustainability Index, Carbon Disclosure Performance Index, and Advanced Sustainable Performance Indices.

The Environment, Social and Governance (ESG) aspects have becoming more important for the participants on the capital market. Because the company is listed on the German stock exchange (and selected the 30 blue 
Vasile J.A. et al.: Implication of the CSR and cultural model features in Romanian...

chip DAX index), the ESG elements have been reported, and E.on is among the first German companies to offer standardized key ESG indicators.

In Romania, E.ON is represented by E.ON Energie and carries multiple social responsibility programs, being involved especially in development of relationships with communities and local education systems. On a year level, the company has allocated one million Euros for social responsibility projects.

\section{Conclusions}

At the international level, the transnational companies have integrated the concept of corporate responsibility in their strategy development and management process, which is related and adapted to inland cultural models. Most companies usually use multiple tools, internationally recognized such principles Global Compact, GRI Sustainable Reporting Guidelines and AA1000 Assurance Standard (to provide guarantees on the reliability and quality performance of the company). Furthermore, they use additional indicators and standards, based on the specific activity, the strategy adopted and pressure from stakeholders.

Very wide applicability of the concept of social responsibility by various entities such as transnational companies, SMEs, public institutions, cities, universities and portfolio investors, included in a larger perspective of the inland cultural model, has led to the emergence of numerous public and private initiatives, the theories and opinions of measuring and reporting, which is why the introduction of ISO 26000 is welcomed.

According to the "Trends and Realities CSR in Romania in 2014" study conducted by CSRMedia.ro and EY Romania, the CSR is a little known concept in Romania, but compared to the previous year, more and more companies engage in CSR projects. (96\% of respondents compared to $86 \%$ in 2013). The main tools for disclosing their social involvement are the press release (31\%), CSR report (26), and the company's website (22\%).

In Romania, the main drivers of CSR are transnational companies which integrate and adapt, usually to their business models, some of the cultural features in order to achieve performance. This situation is found in the energy sector, too, although there are many local companies, some of them listed on the Bucharest Stock Exchange. Therefore, the influence of investors from the capital market is very low, and the promotion of CSR is reduced. In general, CSR works in parallel with the company codes of conduct, and CSR and sustainability issues are often correlated. As in other countries in Central and Eastern Europe, the influences of consumers is low, given the low awareness about energy companies' activities; indebtedness of consumers, high prices of 
Vasile J.A. et al.: Implication of the CSR and cultural model features in Romanian...

energy compared with low average income of population, and thus, the consumers are not able to pay higher price for green energy or energy white (Streimikiene et al., 2009).

The three pillars of social responsibility, namely the economic, environmental and social one, and addition of the cultural features as part of cultural models influence best represented in the case of companies in the energy sector, are aimed at environmental issues such as compliance with the regulations, commitment to emissions reduction, and the development of new technologies.

In the future, we anticipate an improvement in the social involvement of companies in the energy sector in Romania, based on the following considerations: the dynamics of concept at the European and global level, the ability to take and adapt specific best practices from companies abroad and enhance the support provided by public authorities in the field of CSR. In addition, the nature of the activities of the electricity providing companies implies that responsible practices are more important than in others sectors the environmental consequences of electricity generation alone require positive actions (ECOTEC, CSR in the electricity sector (2007).

\section{References}

Aupperle, K., Carroll, A., \& Hatfield, J. (1985). An empirical examination of the relationship between corporate social responsibility and profitability. Academy of Management Journal, 28(2), 446-463.

Chivu, L., Ciutacu, C., \& Hurley, J. (2007). Incomes and working time-support for quality of work and employment in Romania. Romanian Journal of Economics, 25(34), 47-59.

Ciutacu, C., Chivu, L., \& Preda, D. (2005). The social responsibility of the company-a challenge for the contemporary world.

-CS Rmedia.ro Ernst\&Young. (2014). Tendinte si realitati CSR in Romania. Retrieved from

http://www.eyromania.ro/sites/default/files/attachments/EY\%20CSR\%20Survey \%202014 RO.p

Dusmanescu, D., Andrei, J., \& Subic, J. (2014). Scenario for Implementation of Renewable Energy Sources in Romania.Procedia Economics and Finance, 8, 300-305.

-ECOTEC, CSR in the electricity sector. (2007). Describing developments in the European electricity sector. In: Drivers for change: Corporate Social Responsibility - a report to the sectoral social partners, United Kingdom.

-ENEL. (2013). Environmental Report 2013. Retrieved from http://www.enel.com/enGB/doc/report2013/2013 enel environmental report.pdf

-European Commission. (2010). Communication from The Commission to The European Parliament, The Council, The European Economic and Social Committee and The Committee of The Regions, Energy 2020 A strategy for 
Vasile J.A. et al.: Implication of the CSR and cultural model features in Romanian...

competitive, sustainable and secure energy. Brussels. 10.11.2010, COM(2010) 639 final.

-European Commission. (2011). Communication from The Commission to The European Parliament, The Council, The European Economic and Social Committee and The Committee Of The Regions On security of energy supply and international cooperation. (COM/2011/0539 final).

Friedman, M. (1970). The Social Responsibility of Business is to Increase its Profits. The New York Times Magazine, September 13. Retrieved from http://www.colorado.edu/studentgroups/libertarians/issues/friedman-soc-respbusiness.html

Gray, R., Own, D., \& Adams, C. (1996). Accounting \& Accountability: Changes and challenges in corporate social and environmental reporting. Prentice Hall.

Holme, R., \& Watts, P. (2000). Corporate Social Responsibility: Making Good Business Sense. Retrieved from http://www.wbcsd.org/DocRoot/lunSPdIKvmYH5HjbN4XC/csr2000.pdf

McGuire, J., Sundgren, A., \& Schneeweis, T. (1988). Corporate social responsibility and firm financial performance.Academy of Management Journal, 31(4), 854872.

McWilliams, A., \& Siegel, D. (2001). Corporate social responsibility: A theory of the firm perspective. The Academy of Management Review, 26(1), 117-127.

-Ministerul Economiei si Industriei. (2011). Strategia energetică a României pentru perioada 2007-2020 actualizată pentru perioada 2011-2020. Retrieved from http://www.minind.ro/energie/STRATEGIA energetica actualizata.pdf

-NIS. (2014). Anuarul Statistic al României. Serie de date 1990-2012. Bucharest: National Institute of Statistics.

-OECD. (2004). Principles of Corporate Governance. Retrieved from http://www.oecd.org/corporate/ca/corporategovernanceprinciples/31557724.pdf

Posnikoff, J.F. (1997). Disinvestment from South Africa: They did well by doing good. Contemporary Economic Policy,15(1), 76-86.

Streimikiene, D., Simanaviciene, Z., \& Kovaliov, R. (2009). Corporate social responsibility for implementation of sustainable energy development in Baltic States. Renewable and Sustainable Energy Reviews, 13(4), 813-824. doi:10.1016/j.rser.2008.01.007

Tănăsescu, A., Bodea, C.N., \& Pătraşcu, A. (2008). An Environmental Ontology Design. In: International Conference Science and Technology in the Context of Sustainable Development, Petroleum-Gas University of Ploieşti, Ploieşti, November 6-7, Buletinul Universităţii Petrol-Gaze din Ploieşti, Seria Ştiinţe Economice.

Teoh, S.H., Welch, I., \& Wazzan, P.C. (1999). The Effect of Socially Activist Investment Policies on the Financial Markets: Evidence from the South African Boycott. Journal of Business, 72(1), 35-89. doi:10.1086/209602

Waddock, S. (2008). Building a new institutional infrastructure for corporate responsibility. Academy of Management Perspective, 22(3), 87-108.

Waddock, S.A., \& Graves, S.B. (1997). The corporate social performance - financial performance link. Strategic Management Journal, 18(4), 303-319. doi:10.1002/(SICI)1097-0266(199704)18:4<303::AID-SMJ869>3.0.CO;2-G

Wright, P., \& Ferris, S.P. (1997). Agency Conflict and Corporate Strategy: The Effect of Divestment on Corporate Value.Strategic Management Journal, 18(1), 77-83. doi:10.1002/(SICl)1097-0266(199701)18:1<77::AID-SMJ810>3.0.CO;2-R 